\title{
Host-Guest Supramolecular Dendrimers
}

\author{
Mercedes Alvarez Alcalde, ${ }^{1}$ Aida Jover, ${ }^{1}$ Francisco Meijide, ${ }^{1}$ Luciano \\ Galantini, ${ }^{2}$ Nicolae Viorel Pavel, ${ }^{2}$ Alvaro Antelo and José Vázquez Tato ${ }^{1, *}$ \\ ${ }^{1}$ Departamento de Química Física, Facultad de Ciencias, Universidad de Santiago de \\ Compostela, Avda. Alfonso X El Sabio s/n, 27002 Lugo, Spain, \\ ${ }^{2}$ Dipartimento di Chimica, Research center SOFT-INFM-CNR, Università di Roma \\ "La Sapienza", P.le A. Moro 5, 00185 Roma, Italy.
}

\begin{abstract}
The formation of new supramolecular dendrimers from interlocked host/guest unimers is reported. Unimer entities have two host binding sites $(\beta C D)$ and two guest binding sites (two adamantly or two $p$-tert-butylbenzoate moities). Hosts and guest residues are linked through an EDTA bridge. The formation of dendrimer-like (Cayley tree) structures is demonstrated by TEM measurements.
\end{abstract}

\section{Introduction}

Supramolecular chemistry is mainly focused on designing new molecules which, after processes as recognition and assembling, form new entities, usually denoted as complexes, supramolecular assemblies, etc. ${ }^{1}$ Supramolecular polymers consist of arrays of low molecular weight molecules linked by noncovalent interactions. ${ }^{2,3}$

Host/guest chemistry has a growing importance in designing new supramolecular entities as supramolecular polymers. Among them ${ }^{4-6}$ we can mention the guest/host complexes formed by inclusion of organic molecules inside the cavity of cyclodextrins. ${ }^{7}$ During the past few years, descriptions of different supramolecular polymers involving cyclodextrin derivatives have been published. ${ }^{8}$ These polymers can be classified as four main types:

(i) Supramolecular polymers formed from interlocked unimers. The repetitive unimer carries complementary units, i.e., host and guest sites. Examples of this type of polymers have been published. ${ }^{9-14}$

(ii) Supramolecular polymers formed from two complementary monomers having a minimum of two interacting sites. Linear supramolecular polymers are expected when both monomers are ditopic entities. ${ }^{4,6,8,15,16}$

(iii) Polytopic hosts and polytopic guests have been used to form other macromolecular assemblies. ${ }^{17,18}$ 
(iv) Finally, covalent polymers can enter the cavity of the cyclodextrin, forming polyrotaxanes. ${ }^{19}$ These compounds are also known as molecular necklaces. $^{20,21}$

In the literature, much less attention has been paid to the formation of dendrimer-like structures formed by cyclodextrin derivatives. As far as we know only two dendrimers formed by a $\beta \mathrm{CD}$ trimer with two ditopic guests sodium deoxycholate and an adamantyl dymer have been published. ${ }^{5,8}$ In both cases, the host and guest residues belong to two different molecules. However supramolecular dendrimers formed from interlocked unimers, in which the repetitive unimer simultaneously carries the two complementary units (i.e., hosts and guests sites) can also be designed although they have not been yet published in literature. In this paper, we report the formation of dendrimer-like structures from new polytopic hosts/guests unimers (see Figure 1 for structures).

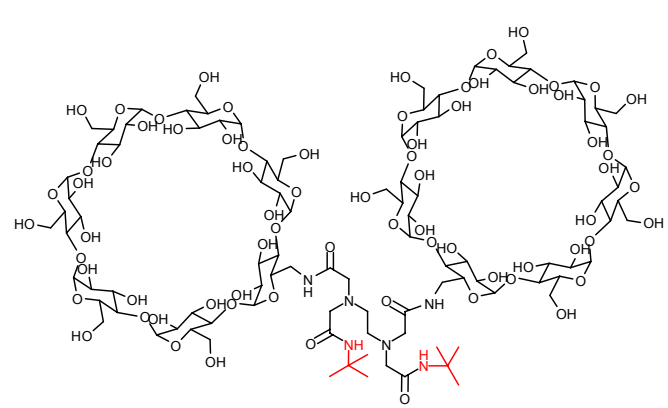

(a) $t$ But2-CD2

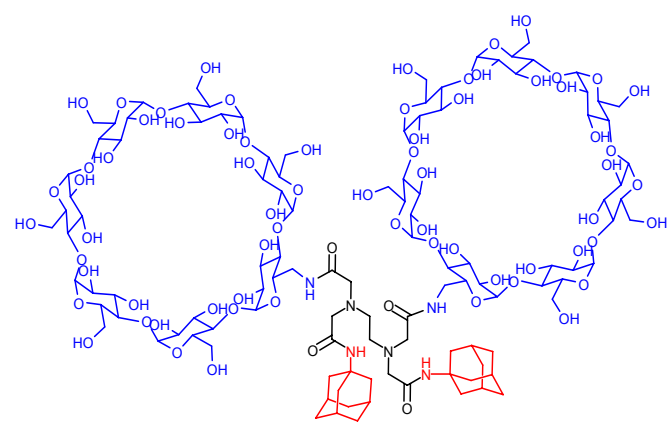

(c) $\mathrm{Ad} 2-\mathrm{CD} 2$

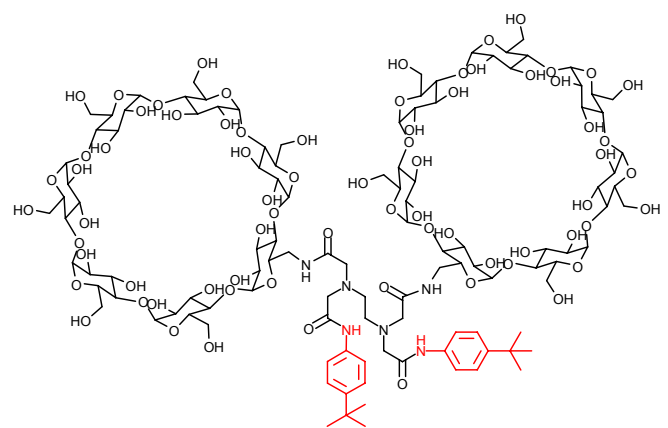

(b) $t \mathrm{BuPh} 2-\mathrm{CD} 2$

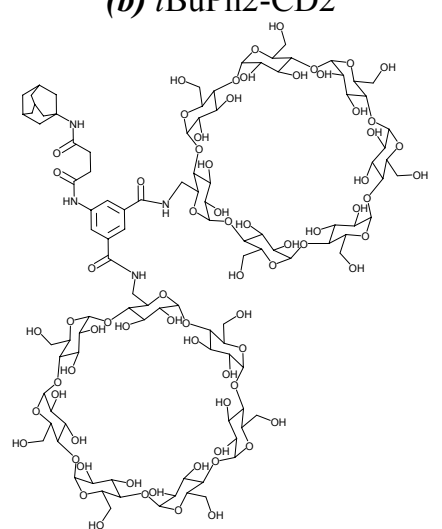

(d) Ad-CD2

Figure 1.- Polytopic hosts/guests unimers. All unimers have two host residues $(\beta \mathrm{CD})$ and either two [(a) $t$-butyl, (b) p-tertbutylphenyl and (c) adamantyl] or one (admantyl) moities. 


\section{Synthesis}

The synthesis of the four unimers were carried out by following either Scheme 1 or Scheme 2.

Scheme 1

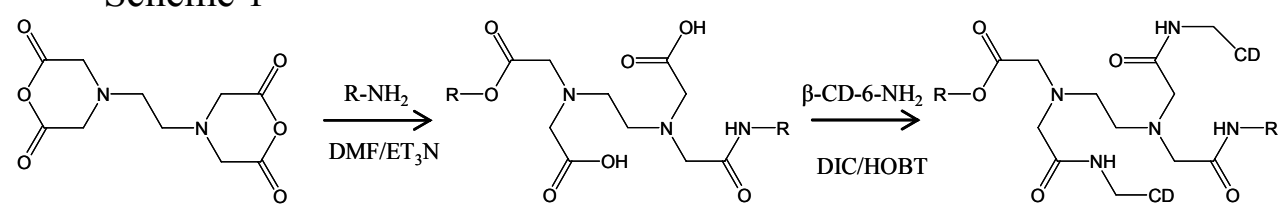

(1)

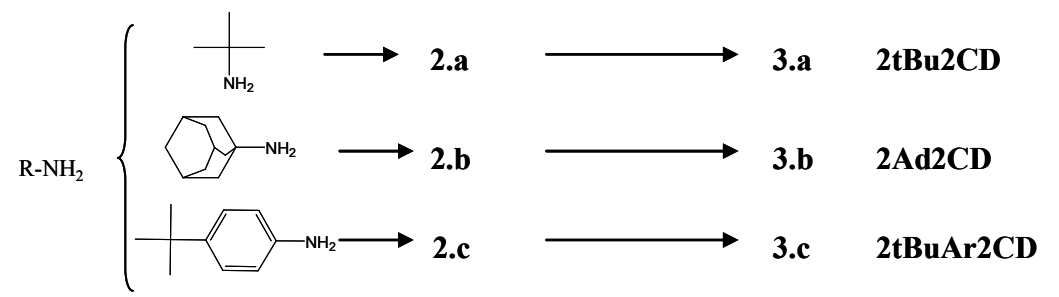

Scheme 2

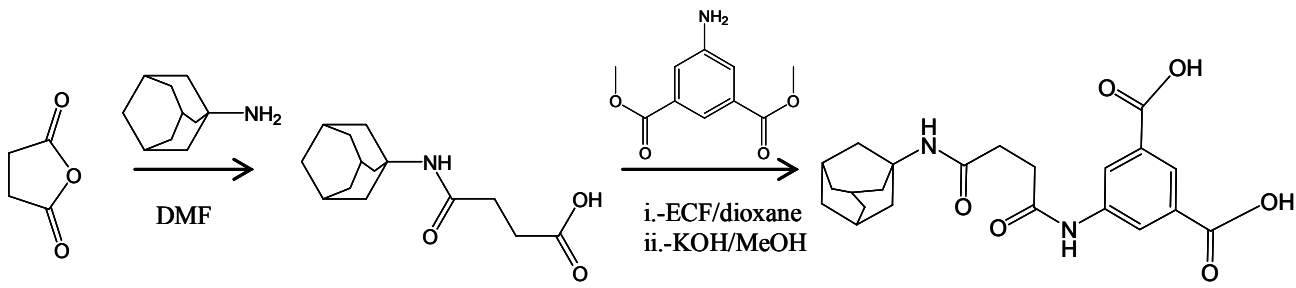

(4) (5)

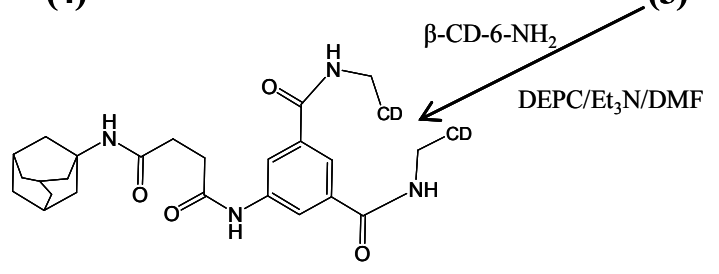

(6)

Synthesis of 2.a: tert-Butylamine $(3 \mathrm{~mL})$ was dropped into a flask with ethylenediaminetetraacetic dianhydride $(1.20 \mathrm{~g}, 5.0 \mathrm{mmol})$ in $20 \mathrm{~mL}$ of dried DMF. The mixture is stirred for 12 hours at r.t., and finally concentrated in vacuo. Solid was dissolved in acidic water and precipitated from acetone. 


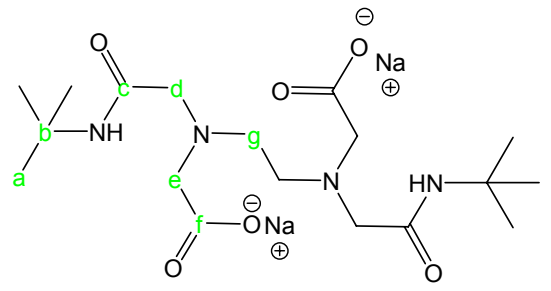

${ }^{1}$ H RMN (DMSO-d6; $\left.300 \mathrm{MHz}, \delta / \mathrm{ppm}\right)$ : $7.51(\mathrm{~s}, \mathrm{H}-\mathrm{N}-\mathrm{C}=\mathrm{O}) ; 3.30$ (s, He); $3.10(\mathrm{~s}, \mathrm{Hd})$; $2.66(\mathrm{~s}, \mathrm{Hi}) ; 1.25$ (s, Ha); ${ }^{13} \mathbf{C}$ RMN; (DMSO-d6; 75 MHz, $\delta / \mathbf{p p m}): 174.53(\mathrm{C}=\mathrm{O}$, carboxylic acid); $170.93(\mathrm{C}=\mathrm{O}$, amide); 58.6 (Ce); $56.9(\mathrm{Cd}) ; 50.1(\mathrm{Cg}) ; 47.4(\mathrm{Cb}) ; 30.1$ $(\mathrm{Ca})$.

Synthesis of 2.b and 2.c: Ethylenediaminetetraacetic dianhydride (2.40 $\mathrm{g}, 10.0 \mathrm{mmol})$ and either 1-adamantine $(3.00 \mathrm{~g}, 20.0 \mathrm{mmol})$ or aromatic amine (3.08 g, $20.0 \mathrm{mmol})$ were dissolved in $20 \mathrm{ml}$ and $30 \mathrm{ml}$ of dried DMF, respectively. In addition, triethylamine $(10 \mathrm{~mL})$ was added. The reaction mixture was stirred for 10 minutes at $0{ }^{\circ} \mathrm{C}$ and then 12 hours at r.t., and finally concentrated in vacuo. The solid was obtained by addition of an acidic solution $(\mathrm{pH}=2)$ and was washed twice with acidic water. The final products were purified by recristallization from methanol.
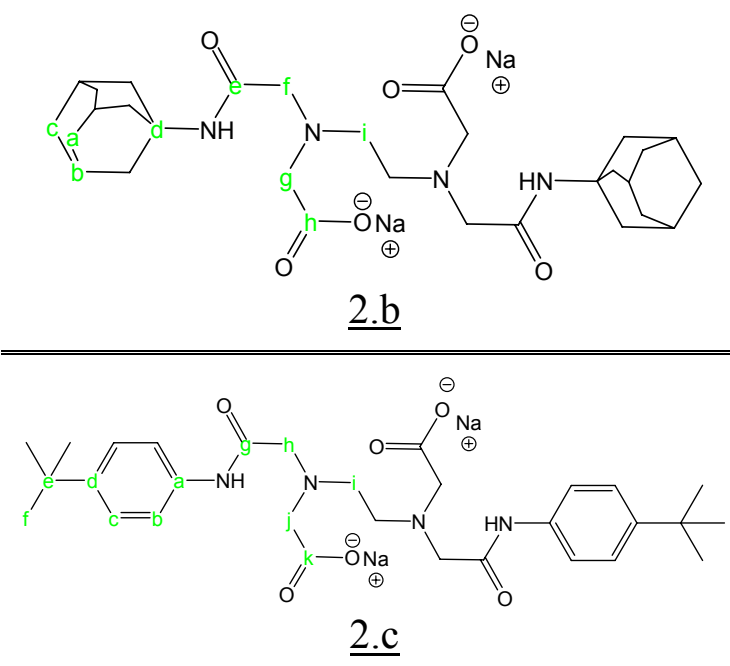

${ }^{1}$ H RMN (DMSO-d6; $\left.300 \mathrm{MHz}, \delta / \mathrm{ppm}\right)$ : 7,42 (s, H-N-C=O); 3.33 (s, Hg); 3.08 (s,Hf); 2.66 (s, Hi); 1.99 (s, Hb); 1.91 (s, Ha); 1.60 (s, Hc). ${ }^{13}$ C RMN; (DMSO-d6; $75 \quad \mathbf{M H z}, \delta / \mathbf{p p m}): \quad 172.67 \quad(\mathrm{C}=\mathrm{O}$, carboxylic acid); $169.38(\mathrm{C}=\mathrm{O}$, amide); $58,8(\mathrm{Cf}) ; 55.9(\mathrm{Cg}) ; 52.3(\mathrm{Ci}) ; 50.4(\mathrm{Cd})$; $41.0(\mathrm{Ca}) ; 35.9(\mathrm{Cc}) ; 28.8(\mathrm{Cb})$. FAB: $559.3 \mathrm{~g} / \mathrm{mol}$.

${ }^{1}$ H RMN (DMSO-d6; 300 MHz, $\delta /$ ppm): $8.48(\mathrm{~s}, \mathrm{H}-\mathrm{N}-\mathrm{C}=\mathrm{O}) ; 7.27$ y $7.16(\mathrm{Ha}, \mathrm{Hb})$; $3.28(\mathrm{~s}, \mathrm{Hj}) ; 3.24(\mathrm{~s}, \mathrm{Hh}) ; 2.71(\mathrm{~s}, \mathrm{Hi})$; 1.23 (s, Hf). ${ }^{13} \mathrm{C}$ RMN; (DMSO-d6; 75 MHz, $\delta \quad / \mathbf{p p m}): \quad 173.5 \quad(\mathrm{C}=\mathrm{O}$, ácido carboxílico); $171.2(\mathrm{C}=\mathrm{O}$, amida); 149.7; $137.1 ; 129.2$ y $127.6(\mathrm{Ca}-\mathrm{Cd}) ; 58.6(\mathrm{Ch})$; $56.7(\mathrm{Cj}) ; 53.3(\mathrm{Ci}) ; 34.8(\mathrm{Ce}) ; 31.7(\mathrm{Cf})$.

Synthesis of $\underline{3 . a}, \underline{3 . b}$ and $\underline{3 . c}$ : In a dry $100 \mathrm{~mL}$ flask, the derived amine $(0.6 \mathrm{mmol})$, HOBT $(0.27 \mathrm{~g}, 2.0 \mathrm{mmol})$ and $0.25 \mathrm{ml}$ of DIC were mixed in 10 $\mathrm{mL}$ of dried DMF and a solution of $\beta-\mathrm{CD}-6 \mathrm{NH}_{2}(2 \mathrm{~g}, 2.0 \mathrm{mmol})$ in $10 \mathrm{~mL}$ of dried DMF. The reaction mixture was stirred at r.t. for 24 hours and then, $0.25 \mathrm{~g}$ of HOBT, $0.25 \mathrm{ml}$ of DIC and $1.2 \mathrm{~g}$ of $\beta-\mathrm{CD}-6 \mathrm{NH}_{2}$ were added. The final product was purified by a Sephadex column. Overall yield $81 \%, 70 \%$ and $63 \%$, respectively.

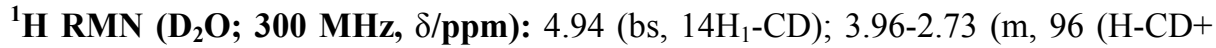

3.a $\left.\left.\mathrm{H}_{\mathrm{EDTA}}\right)\right) ; 1.30$ (s, 18Ha). MALDI-TOF: [M+Na] $\mathrm{m} / \mathrm{z} 2655.9880$ calcd for $\mathrm{C}_{102} \mathrm{H}_{171} \mathrm{~N}_{6} \mathrm{NaO}_{72}$ Found: 2655.9867 . 


\begin{tabular}{|c|c|}
\hline & ${ }^{1} \mathbf{H}_{\text {RMN }}\left(\mathbf{D}_{\mathbf{2}} \mathbf{O} ; 300 \mathrm{MHz}, \delta / \mathbf{p p m}\right): 4.94$ (bs, $\left.14 \mathrm{H}_{1}-\mathrm{CD}\right) ; 3.92-2.79$ (m, 96 (H-CD+ \\
\hline 3.b & $\begin{array}{l}\left.\mathrm{H}_{\text {EDTA }}\right) \text { ); } 1.68 \text { (bs, 12Hc). MALDI-TOF: [M+K] } \mathrm{m} / \mathrm{z} 2828.0558 \text { calcd for } \\
\mathrm{C}_{114} \mathrm{H}_{183} \mathrm{~N}_{6} \mathrm{KO}_{72} \text { Found: } 2828.1250 \text {. }\end{array}$ \\
\hline 3.c & 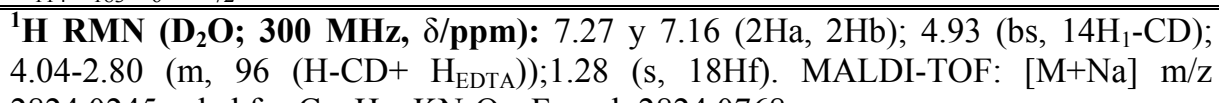 \\
\hline
\end{tabular}

Synthesis of $\underline{4}$ : Succinic anhydride $(0.45 \mathrm{~g}, 4.5 \mathrm{mmol})$ dissolved in dry DMF $(10 \mathrm{~mL})$ was added to a solution of freeze-dried 1-Adamantanamine $(0.54 \mathrm{~g}, 3.6 \mathrm{mmol})$ in dry DMF $(12 \mathrm{~mL})$. The reaction mixture was stirred for 6 $\mathrm{h}$ at r.t. under argon. After evaporation of the solvent, solid was dissolved in methanol and kept in freeze until crystallization.

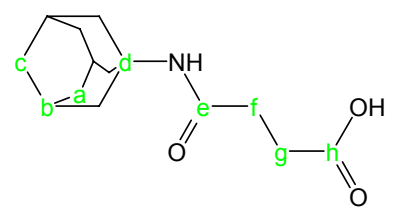

Adsucc
${ }^{1}$ H RMN (DMSO-d6; 300 MHz, $\delta /$ ppm): 7.17 (s, H-N-C=O); 2.34 (t, Hg); 2.25 (t,Hf); 1.89 (s, Hb); 1.87 (s, Ha); 1.59 (s, Hc). ${ }^{13}$ C RMN; (DMSO-d6; 75 MHz, $\delta /$ ppm): 174.53 (C=O, carboxylic acid); $170.93(\mathrm{C}=\mathrm{O}$, amide); $51.3(\mathrm{Cd}) ; 41.2(\mathrm{Ca})$; $36.8(\mathrm{Cc}) ; 31.6(\mathrm{Cf}) ; 30.0(\mathrm{Cg}) ; 24.5(\mathrm{Cb})$.

Synthesis of 5: Adsucc $(2.0 \mathrm{~g}, 8.0 \mathrm{mmol})$ and tri- $n$-butyl-amine $(1.9 \mathrm{~g}$, $8.0 \mathrm{mmol}$ ) were dissolved in $15 \mathrm{ml}$ of dioxane. The solution was maintained at $8{ }^{\circ} \mathrm{C}$ and ethylchloroformate $(1.0 \mathrm{ml}, 10.0 \mathrm{mmol})$ was added with stirring under argon. After 15 minutes a solution of dimethyl 5-aminobenzene-1,3-dioate $(2.11 \mathrm{~g}, 10.0 \mathrm{mmol})$ in $15 \mathrm{ml}$ of dioxane was added. After removing the icewater bath the reaction was maintained for $1 \mathrm{~h}$ at r.t. and finally for $1 \mathrm{~h}$ at $65^{\circ} \mathrm{C}$. After this time the solvent was removed in vacuo. Then $200 \mathrm{ml}$ of ethyl acetate were added and washed twice with water $(50 \mathrm{ml})$ to remove all dioxane. The organic phase was dried $\left(\mathrm{Na}_{2} \mathrm{SO}_{4}\right)$ and totally evaporated under reduced pressure. Finally the crude product was dissolved in methanol. When the solution is cooled the compound precipitates after 2 hours. The solid was filtered and washed with ether and dried in a vacuum oven. To remove the methyl groups, the compound was refluxed with $\mathrm{KOH} 1 \mathrm{M}$ in methanol for 1 hour at $80^{\circ} \mathrm{C}$. The solvent was evaporated and the solid redissolved in water $(200 \mathrm{~mL})$ and acidified with $\mathrm{HCl}(\mathrm{pH}=1)$. The compound precipitates in its diacid form when the solution is cooled.

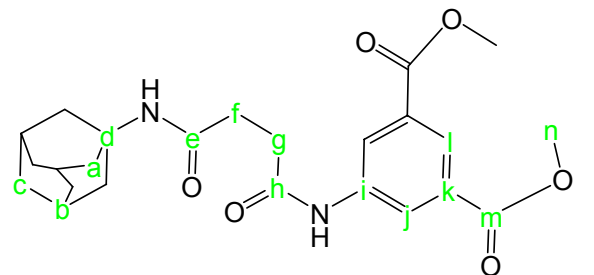

5-diester
${ }^{1}$ H RMN (DMSO-d6; 300 MHz, $\left.\delta / \mathbf{p p m}\right): 10.28$ (s, Ar-NH-C=O); $8.45(\mathrm{~s}, \mathrm{Hj}) ; 8.12(\mathrm{~s}, \mathrm{Hl}) ; 1.89(\mathrm{~s}$, $\mathrm{Hb}) ; 3.87$ (s, Hn); 2.36 (s, Hf,Hg); 1.96 (s, Hb); $1.84(\mathrm{~s}, \mathrm{Ha}) ; 1.58(\mathrm{~s}, \mathrm{Hc})$. 
Synthesis of $\underline{6}$ : $\underline{5}(0.25 \mathrm{~g}, 0.5 \mathrm{mmol})$ was dissolved in $5 \mathrm{~mL}$ of dried DMF. DEPC $(0.25 \mathrm{ml}, 1.65 \mathrm{mmol})$ were added to this solution. After 20 minutes at r.t. a solution of $\beta-\mathrm{CD}-6 \mathrm{NH}_{2}(1.5 \mathrm{~g}, 1.3 \mathrm{mmol})$ in $5 \mathrm{~mL}$ of dried DMF was added with stirring under argon. After 10 minutes the solution was cooled to $0{ }^{\circ} \mathrm{C}$ and then triethylamine $(0.4 \mathrm{ml})$ was added. After 30 minutes the solvent was removed in vacuo. Finally the crude product was acidified with $\mathrm{HCl}(\mathrm{pH}=4-5)$ and purified through a Sephadex column. Identity of the compound was confirmed by NMR and purity by TLC. Yield $64 \% .{ }^{1} \mathbf{H}$ RMN

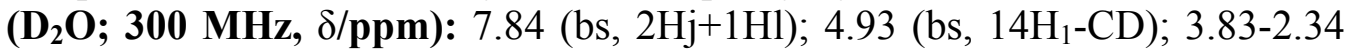
(m, 84H-CD); 2.20 (bs, 2Hf+2Hg); 1,96 (s, 3Hb); 1,84 (s, 6Ha); 1,68 (s, 6Hc). MALDI-TOF: [M+Na] m/z 2683.8932 calcd for $\mathrm{C}_{106} \mathrm{H}_{163} \mathrm{~N}_{4} \mathrm{KO}_{72}$ Found: 2683.9100 .

\section{Results and Discussion}

Figure 2 shows TEM images of dendritic (Cayley tree) entities derived from $t \mathrm{ButPh} 2-\mathrm{CD} 2$ and $\mathrm{Ad} 2-\mathrm{CD} 2$, reminding those observed for other systems. ${ }^{8}$ These images confirm the formation of the expected branched polymers. Figure $2 \mathrm{~d}$ evidences that these branches are also ramified and that this ramification probably extends to the molecular level, although the minimum width of the branches $(=52 \pm 12)$ that we have been able to measure is too far from observing the Cayley tree at a molecular level. According to thermodynamic isodesmic models, ${ }^{3,22}$ formation of these dendrimers are favorable due to the high complexation constants for the formation of adamantyl $/ \beta C D^{23}$ and $t$-Butylphenyl $/ \beta C D^{24}$ complexes $\left[(1-10) \times 10^{4} \mathrm{M}^{-1}\right.$ and 1 5) $\times 10^{4} \mathrm{M}^{-1}$, respectively]. No dendrimer-like images were observed for the other two compounds probably due to low values for equilibrium constant involved, steric effects or that the excess of one of the cyclodextrin units would act as stopper in dendrimer growth. Figure 3 shows 3D molecular models of $\mathrm{Ad} 2-\mathrm{CD} 2$ and $t \mathrm{ButPh} 2-\mathrm{CD} 2$. It can be noticed that if the host entity is smaller than these ones, the steric hindrance due to proximity of large cyclodextrin moities would avoid the inclusion of the guest inside the host as for instance for the tert-butyl groups in $t$ But2-CD2.

No increase of viscosity of aqueous solution was observed as in the mixture of monofunctional and bifunctional cyclodextrin derivatives forming fibrous supramolecular polymers. ${ }^{25}$ 


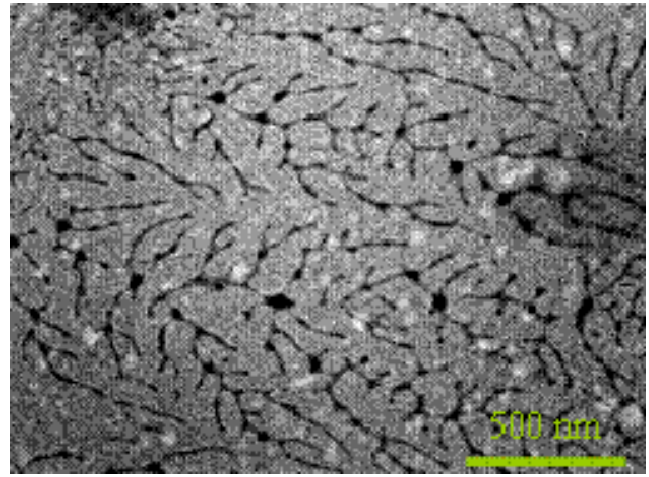

(a)

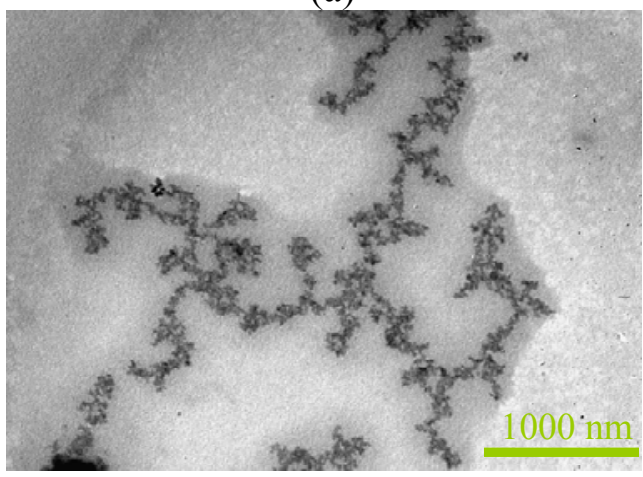

(c)

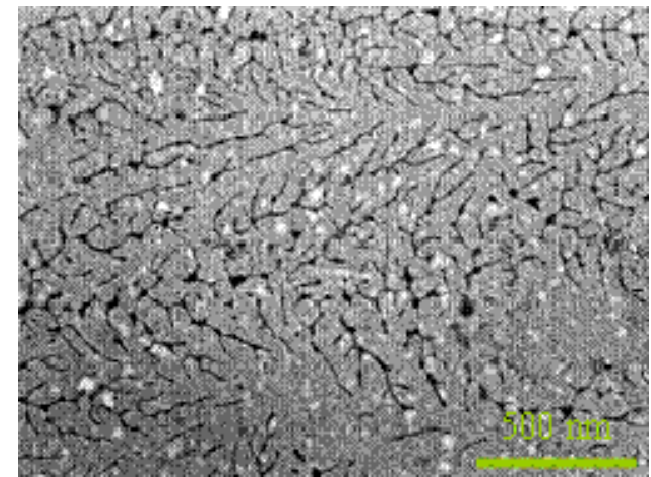

(b)

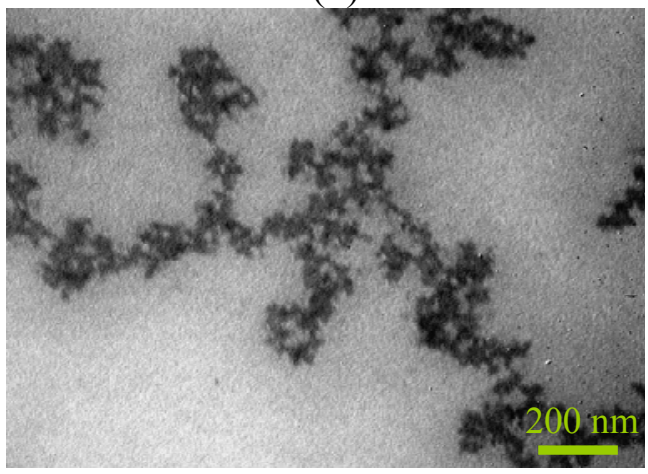

(d)

Figure 2.- TEM images obtained from solutions of (a) $[\mathrm{Ad} 2-\mathrm{CD} 2]=1 \mathrm{mM}$ in $\mathrm{D}_{2} \mathrm{O}$, (b) $[t \mathrm{BuPh}$ $2 \mathrm{CD} 2]=2 \mathrm{mM}$ in $\mathrm{D}_{2} \mathrm{O}$, (c) $[\mathrm{Ad} 2-\mathrm{CD} 2]=5 \mathrm{mM}$ in $\mathrm{D}_{2} \mathrm{O}$ at $40^{\circ} \mathrm{C}$. (d) Enlargement of (c). Deuterium oxide is used to avoid bacteria growth.

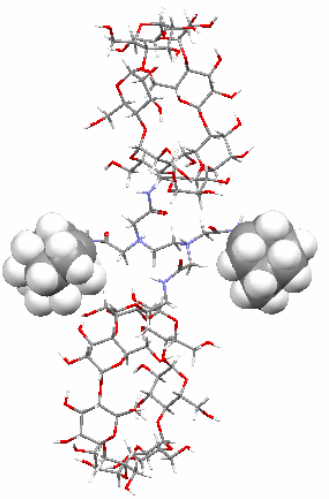

(a)

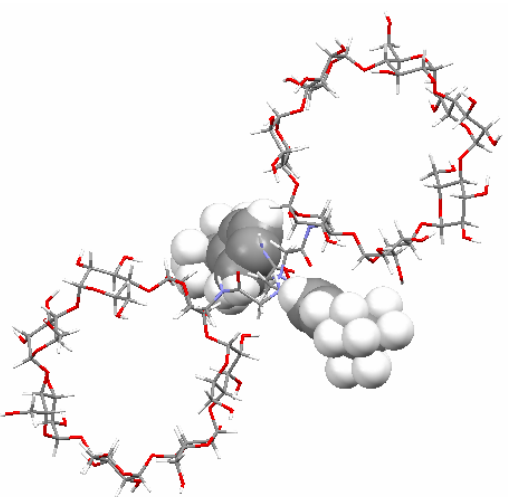

(b)

Figure 3.- 3D model of (a) Ad2-CD2 and, (b) $t$ ButPh2-CD2. 
Acknowledgment. The authors from USC thank the Ministerio de Ciencia y Tecnología (Project MAT2004-04606) and Xunta de Galicia (PGIDIT05PXIC26201PN) for financial support. The authors from 'La Sapienza' thank the MIUR financial supports (FIRB project RBIN04PWNC and PRIN 2006).We also thank for the Spain-Italy Integrated Action grants.

\section{References}

1. Lehn, J.-M. Supramolecular Chemistry; VCH: Weinheim, 1995.

2. Ciferri, A. Macromolecular Rapid Communications 2002, 23(9), 511-529.

3. A. Ciferri, ed. Supramolecular Polymers, 2nd Edition; Taylor $\neg$ Francis: New York, 2005.

4. Ramos Cabrer, P.; Alvarez-Parrilla, E.; Meijide, F.; Seijas, J. A.; Rodríguez Núñez, E.; Vázquez Tato, J. Langmuir 1999, 15, 5489-5495.

5. Alvarez Parrilla, E.; Ramos Cabrer, P.; Al-Soufi, W.; Meijide, F.; Rodríguez Núñez, E.; Vázquez Tato, J. Angew. Chem. Int., Ed. 2000, 39, 2856-2858.

6. Alvarez Parrilla, E.; Ramos Cabrer, P.; Singh, A. P.; Al-Soufi, W.; Meijide, F.; Rodríguez Núñez, E.; Vázquez Tato, J. Supramol. Chem. 2002, 14, 397-404.

7. Szejtli, J. Cyclodextrin Technology; Kluwer Academic Publishers: Dordrecht, The Nederlands, 1988.

8. Soto Tellini, V. H.; Jover, A.; Carrazana Garcia, J.; Galantini, L.; Meijide, F.; Vázquez Tato, J. J. Am. Chem. Soc. 2006, 128, 5728-5734.

9. Hirotsu, K.; Higuchi, T.; Fujita, K.; Ueda, T.; Shinoda, A.; Imoto, T.; Tabushi, I. J. Org. Chem. 1982, 47, 1143-4.

10. Mentzafos, D.; Terzis, A.; Coleman, A. W.; deRango, C. Carbohyd. Res. 1996, 282, 125-35.

11. Liu, Y.; Fan, Z.; Zhang, H.-Y.; Diao, C.-H. Org. Lett. 2003, 5, 251-254.

12. Harada, A.; Kawaguchi, Y.; Hoshino, T. J. Inclusion Phenom. Macrocyclic Chem. 2001, 41, 115-121.

13. Tellini, V. H. S.; Jover, A.; Galantini, L.; Meijide, F.; Tato, J. V. Acta Cryst. 2004, B60, 204-210.

14. Miyauchi, M.; Takashima, Y.; Yamaguchi, H.; Harada, A. J. Am. Chem. Soc. 2005, 127, 2984-2989.

15. Liu, Y.; Wang, H.; Liang, P.; Zhang, H.-Y. Angew. Chem. Int. Ed. 2004, 43, 2690-2694.

16. Leggio, C.; Anselmi, M.; Di Nola, A.; Galantini, L.; Jover, A.; Meijide, F.; Pavel, N. V.; Soto Tellini, V. H.; Tato, J. V. Macromolecules 2007, 40, 5899-5906.

17. Amiel, C.; Moine, L.; Sandier, A.; Brown, W.; David, C.; Hauss, F.; Renard, E.; Gosselet, M.; Sebille, B. ACS Symp. Ser. 2001, 780, 58-81.

18. Wenz, G.; Weickenmeier, M.; Huff, J. ACS Symp. Ser. 2000, 765, 271-283.

19. Harada, A.; Okada, M.; Kawaguchi, Y.; Kamachi, M. Polym. Adv. Technol. 1999, 
10, 3-12.

20. Harada, A.; Li, J.; Kamachi, M. Nature 1992, 356, 325.

21. Park, K.-M.; Kim, S.-Y.; Heo, J.; Whang, D.; Sakamoto, S.; Yamaguchi, K.; Kim, K. J. Am. Chem. Soc. 2002, 124, 2140-2147.

22. Zhao, D.; Moore, J. S. Org. Biomol. Chem. 2003, 1, 3471-3491.

23. Carrazana, J.; Jover, A.; Meijide, F.; Soto, V. H.; Vázquez Tato, J. J. Phys. Chem. 2005, 109, 9719-9726.

24. Hoefler, Th.; Wenz, G. J. Inclusion Phenom. Mol. Recognit. Chem. 1996, 25, 8184.

25. Miyawaki, A.; Takashima, Y.; Yamaguchi, H.; Harada, A. Chem. Lett. 2007, 36, 828-829. 